\title{
O odnosu mitskog i političkog u djelima Ernesta Laclaua
}

\author{
VEDRAN JERBIĆ \\ MA student, European studies, \\ Fakultet političkih znanosti Sveučilišta u Zagrebu
}

\begin{abstract}
Rad se bavi konceptualnim odnosom mitskog i političkog u djelima političkog teoretičara Ernesta Laclaua. Poststrukturalistička i postmarksistička perspektiva iz koje Laclau progovara prožeta je snažnim anitesencijalističkim etosom te usmjerena dekonstrukciji naturalizacije i totalizacije označiteljskih praksi unutar političkog polja. Za Laclaua mit stvara "novi prostor reprezentacije" i time se pojavljuje kao kritička točka naspram diskursa dominantnog poretka. Kako bismo adekvatno odgovorili na postavljeni problem, u radu se analizira i Laclauova distinkcija između društva i društvenog, jednako kao i koncept socijalnog imaginarija. Također se u kratkim crtama osvrćemo na neke od autora koji su utjecali na Laclauovu teorijsku poziciju: Sorela, Schmitta, Derridu...
\end{abstract}

Ključne riječi: mit, političko, diskurs, poststrukturalizam, antagonizam

Krenimo s definicijom, odnosno nemogućnošću iznalaženja konačne definicije mita i mitskog. Cassirer primjećuje kako nebrojene teorije o mitu "koliko god bile divergentne po svom sadržaju [...] pokazuju isti metodološki stav. Nadaju se da će nam mitski svijet objasniti pomoću intelektualne redukcije" (Cassirer 1978: 103). Je li i sam Cassirer podlegao takvoj "intelektualnoj redukciji” svodeći mit i mitsko na pra-simboličku formu (iz kojega su se kasnije razvile i sve ostale čovjekove simboličke forme), pitanje je koje ćemo ostaviti sa strane, a svoje ćemo izlaganje usmjeriti prema teoretiziranju o nerazmrsivoj povezanosti mitskog i političkog kako ga iz postmarksističke ${ }^{1}$ i poststrukturalističke perspektive vidi Ernesto Laclau, ${ }^{2}$ dekonstruirajući

\footnotetext{
${ }^{1}$ Ovako Laclau i Mouffe sumiraju temeljne odrednice svog postmarksizma: "On se sastoji u produbljivanju tog relacionog momenta koji je Marx, razmišljajući unutar hegelovskog i, u svakom slučaju, devetnaestostoljetne matrice, mogao samo dotle da razvije. U dobu u kojem je psihoanaliza pokazala da akcije nesvjesnog čine sva označavanja dvosmislenim; u kojem nas je razvoj strukturalne lingvistike osposobio za bolje shvaćanje funkcioniranja čisto diferencijalnih identiteta, u kojem je transformacija misli - od Nietzschea do Heideggera, od pragmatizma do Wittgensteina - odlučno potkopala filozofski esencijalizam, možemo reformulirati materijalistički program na radikalniji način nego što je to bilo moguće za Marxa" (Laclau i Mouffe 2007: 11).

${ }^{2}$ Ernesto Laclau (1935.-2014.) je iza sebe ostavio signifikantan opus čiji je interdisciplinarni etos, iako primarno političko teorijski, plodno orijentiran prema psihoanalizi i lingvistici, usmjeren
} 
"klasičnu" opreku između mythosa i logosa i postavljajući uz pomoć teorije diskursa promišljanje o mitu i mitskom na sasvim drukčije temelje. Svrha ovoga rada je, osim geneze konceptualnog odnosa o kojem je riječ, izvesti i metodološke posljedice s obzirom na širu perspektivu teorije diskursa koja se razvila iz opusa Ernesta Laclua (i Chantal Mouffe). ${ }^{3}$ Iz poststrukturalističke pozicije, kojoj Laclau nedvojbeno pripada, epistemološka mogućnost utemeljenja univerzalno važeće Istine čija bi “objektivnost" jamčila demitologizaciju i deideologizaciju društveno-političkog polja - više se ne može uzeti kao ("transcendentalni") činitelj spoznajnog procesa. Ili, kako to formulira Lalović:

$[0]$ sporavanjem same kartezijanske ideje Čovjeka-Subjekta kao mjere i temelja svih stvari osporava se i ideja postojanja nekog posljednjeg Temelja opstojanja društva u "doba nihilizma". Čovjek i njegovo društveno bivstvovanje time su izručeni posvemašnjoj neizvjesnosti, kontingenciji, gubljenju svih supstancijalnih repera samoozbiljenja. (Lalović 2012: 177)

S tim "krhkim" metodološkim predispozicijama teoretiziranje o mitskom sasvim se sigurno ne može više osloniti na klasični prosvjetiteljsko-racionalistički shematizam koji mit poima kao nešto iracionalno, predlogično, predcivilizacijsko, primitivno... Mnogo nam je bliža perspektiva Lévija-Straussa, koji tvrdi da je svaka (re)interpretacija mita i sama mit, odnosno da "ne postoji 'prava' verzija koje bi sve druge bile kopije ili deformirani odjeci. Sve verzije pripadaju mitu" (Lévi-Strauss 1989: 227). I mit o Edipu i Freudova interpretacija toga mita na istoj su diskurzivnoj razini te samim time potraga za izvorom mita, ili pra-mitom, gdje navodno leži pravo značenje naknadnih interpretacija, gubi svoj smisao.

Kako ističe Derrida, Lévi-Straussova specifičnost očituje se "u statusu koji pripisuje vlastitu diskursu o mitovima, onome što naziva svojim "mitologikama'. To je trenutak kada njegov diskurs o mitu sam sebe promišlja i kritizira" (Derrida 2007: 304). Ukoliko je proučavanje mitova, dakle, "metodološki problem" utoliko je svaki iskaz o mitovima i sam mito-morfan i nema načina na da se umakne tom epistemološkom "usudu" u neki utješni, utopijski empirizam ili da se posegne za nekim "transcendentalnim označenim" koji će stajati kao središte strukture.

dekonstrukciji ortodoksnih marksističkih kategorija te obilježen promišljanjem statusa (nove) ljevice u atmosferi njezina napuštanja radikalnog naslijeđa i prihvaćanjem neoliberalnih "pravila igre". Iako je svoje najvažnije djelo napisao u koautorstvu s Chantal Mouffe (Hegemony and Socialist Strategy) te ih se nerijetko sumira kao "jedan glas", u ovom ćemo se radu baviti Laclauovom pozicijom i teorijama koje ponajprije obilježavaju njegov opus.

${ }^{3}$ Riječ je o čitavoj “školi” diskurzivne analize koja se razvila iz njihova opusa sa "sjedištem” na sveučilištu u Essexu, a koja pored spomenutog dvojca okuplja i ostala zvučna imena poput Davida Howartha, Yannisa Stavrakakisa, Jasona Glynosa, Olivera Marcharta i Jacoba Torfinga. 
Ako su temelji čitave naše kulture i znanosti nastali na mitu, ${ }^{4}$ Cassirer, $\mathrm{s}$ druge strane, smatra da se mora zadržati i uspostaviti opreka između mita i ostalih formi koje se postupno osamostaljuju od svojih mitskih temelja. Iako je mit "ne samo veoma udaljen od te empirijske stvarnosti, već je, u izvjesnom smislu, u očiglednoj suprotnosti s njom" (Cassirer 1972: 72), izgrađujući "fantastični svijet" u čije motive (primitivni) čovjek ne može proniknuti, s vremenom se pojavljuje svojevrsna refleksija o mitskim praksama, trenutak kada se u gotovo paradigmatskom pomaku u sustavu ljudskog znanja postavlja pitanje zašto. Cassirer to ovako objašnjava:

Čovek se više ne zadovoljava time što radi izvesne stvari - on postavlja pitanje što te stvari "znače", on istražuje zašto i otkuda, pokušava da shvati odakle su te stvari došle i kuda smeraju. Odgovor koji on daje na sva ta pitanja može izgledati nelogičan i besmislen; no tu nije toliko važan odgovor koliko samo pitanje. Čim počne da se pita povodom svojih postupaka, čovek je učinio nov odlučan korak, stupio je na nov put koji će ga na kraju odvesti daleko od njegovog nesvesnog i nagonskog života. (Cassirer 1972: 72)

Laclauov odnos spram mita pripada "skeptičnoj" ${ }^{5}$ struji odnosa spram mythosa i logosa, on, nasuprot Cassireru, više ne može povući jasnu distinkciju između "temelja" i kasnijih simboličkih formi. Mit ne promatra u odnosu prema istini ili mogućnosti spoznaje, već uz pomoć funkcije proizvodnje značenja i cirkulacije znakova u diskurzivno-historijskim formacijama. Doduše, vrlo je lako odatle skliznuti u postmodernistički relativizam, ili kao što Milivoj Solar primjećuje, govoreći o odnosu postmodernizma prema mitu i mitskom:

Ako prema tome, postmodernizam osporava mit kao neku temeljnu strukturu uspostavljenih značenja, ako ga osporava u smislu ishodišta mogućih značenja i svojevrsnog početka spoznaje, on ga nipošto ne osporava u njegovoj djelatnosti proizvođenja značenja, jer dokidanjem svih vrijednosnih razlika predlaže zapravo samo beskonačnu širinu pripovijedanja bez pravog početka i završetka, koje se prirodno može nekako učvrstiti i učiniti cjelovitim jedino u ponavljanjima i varijacijama. (Solar 2000: 92)

Laclau ipak ne upada u takav (postmodernistički) relativizam niti je njegovo problematiziranje mita i mitskog obilježeno "dokidanjem svih vrijednosti" i "beskonačnom širinom pripovijedanja bez pravog početka i kraja", što će ovaj rad i pokazati. Dapače, opus mu je intenzivno obojen poststrukutralističkim

\footnotetext{
4 “Čak je i nauka morala proći kroz mitsko doba prije nego što je dospjela do logičkog: alkemija je prethodila kemiji, astrologija je prethodila astronomiji" (Cassirer 1972: 53).

${ }^{5}$ Neki bi takvu poziciju denuncirali kao tipično postmodernističku, a drugi vjerojatno kao epistemološko relativističku.
} 
antiautoritarnim etosom i usmjeren prema politici koja, odbacujući ideju konačnih istina i temelja, otvara prostor za redefiniranje demokracije i novih mogućnosti emancipacije.

\section{OD REPREZENTACIJE PREMA ARTIKULACIJI}

Prije nego što se detaljnije pozabavimo samim konceptom političkog, važno je uputiti na doprinos toj temi Georgesa Sorela iz njegovih Razmišljanja o nasilju, s kojim Laclau nerijetko polemizira i kojemu mnogo duguje u svojem promišljanju o mitskom. Sorel polazi od toga da "ljudi koji sudjeluju u velikim društvenim pokretima zamišljaju svoje buduće djelovanje kao bitke koje će njihovu stvar dovesti do pobjede" (Sorel 1980: 17). Takva "zamišljanja" naziva mitovima, a suprotstavlja ih utopijama koje su "rezultat intelektualnog rada [...] djelo teoretičara koji, nakon što su promatrali činjenice i o njima raspravljali, pokušavaju načiniti model s kojim bi mogli usporediti postojeća društva kako bi izmjerili njihove dobre loše strane" (Sorel 1980: 24). Mit je, dakle, revolucionaran dok utopija teži reformizmu, pri čemu revolucionarna aktivnost prožeta mitskim zamišljajima služi kao unificirajuće oruđe otuđene klasne svijesti usmjerujući proletarijat prema njegovoj historijskoj zadaći.

Mit se ne može opovrgnuti, jer je identičan s uvjerenjima neke grupe, jer predstavlja izraz tih uvjerenja u govoru kretanja i jer ga se, zbog toga, ne može rastaviti na dijelove koji bi se mogli primijeniti na planu historijske deskripcije. (Sorel 1980: 25)

Iz antiesencijalitičkog i antiredukcionističkog Laclauovog rakursa, usmjerenog dekonstrukciji marksističke topografije baze i nadgradnje te deprivilegiranju klase s njezine pozicije središnjeg agenta historijske dinamike, Sorelova pozicija mora biti podvrgnuta kritičkom preispitivanju. Kako nijedna društvena skupina nije ontološki predodređena objektivnohistorijskim nužnostima da preuzme zadatak univerzalne emancipacije, Laclau kolektivne identitete promatra kao rezultat hegemonijske borbe čija je logika artikulacijska a ne reprezentacijska. ${ }^{6}$ Iz takve teorijske perspektive sorelovski mit ne može apriori jamčiti jedinstvo klasne svijesti i formiranje proletarijata. U hegemonijskom su polju de-supstancijalizirane subjektne pozicije upućene na artikulacije svojih identifikacijskih pozicija, one ne

\footnotetext{
${ }^{6}$ U knjizi Hegemony and Socialist Strategy Laclau i Mouffe definiraju artikulaciju kao "svaku praksu koja uspostavlja odnose između elemenata, pa je rezultat tih odnosa preoblikovanje tih identiteta. Strukturirani totalitet koji rezultira takvom artikulatornom praksom nazvat ćemo diskurs. Različite pozicije, ako se pojavljuju artikulirane unutar diskursa, nazvat ćemo momentima. Nasuprot tome, elementom ćemo nazvati svaku razliku koja nije diskurzivno artikulirana" (Laclau i Mouffe 2001: 105).
} 
postoje izvan tog "činjenja" i "imenovanja", njihova nestalna "supstancijalnost" je produkt mitskog okupljanja, a ne neke pre-definirane realnosti u kojoj su njihovi identiteti fiksirani i transparentni. Pritom su čak i mitsko konstruirani identiteti za Laclaua nadodređeni drugim identifikacijskim odnosima i ne mogu biti svedeni tek na jednu, središnju subjektnu poziciju. "Simbolički - nadodređeni - karakter društvenih odnosa stoga implicira da isti ne posjeduju krajnju literarnost koja bi ih svela na trenutke odvijanja imanentnog zakona. Ne postoje dvije razine, jedna esencije a druga prikaza, jer nije moguće fiksirati krajnje doslovno značenje za koje bi simboličko bila drugo i izvedena razina" (Laclau i Mouffe 2001: 98). Odnosno, identifikacija koja podrazumijeva "konstitutivni rascjep svih socijalnih identiteta" (Laclau i Zac 1994: 35) uvijek je već proces osuđen na neuspjeh, no taj neuspjeh neumorno hrani svaki novi pokušaj. Lakanovski rečeno, svaki "Ja" je zaslon kojim se branimo od neke temeljne ontološke praznine i sve naše priče-onama-samima i simbolički mandati koje preuzimamo tokom života izgrađeni su oko tog neizdrživog "bezdana".

\section{POLITIČKO KAO ODGOVOR NA NEMOGUĆNOST DRUŠTVA}

Političko se, kao što je već dobro poznato, mora poimati drukčije od politike i ta se distinkcija u okviru političke teorije i filozofije naziva politička razlika (usp. Lalović 2012; Marchart 2007). Političko je pritom, da upotrijebimo heideggerovsku terminologiju, ontološki obzor koji oblikuje sam "okvir", odnosno mogućnost pojavljivanja socijalno-normativnih praksi, dok je politika ontički "sadržaj" koji ispunjava to polje ontološke "prisutnosti" (usp. Marchart). Upravo u nemogućnosti ontičkog aspekta politike da bez ostatka obuhvati i ovlada ontološkim aspektom političkog, nastaje i održava se "stvarnost" jedne epohe, mogućnost emancipacije i napretka, ali i totalitarnog ekscesa i regresije u okrutni barbarizam. Kao niz instrumentalnoinstitucionalnih odluka i praksi politika može biti objašnjena tek u svojem ontičkom obliku, dok analiza političkog uključuje širi kontekst promišljanja o "strukturalnim" karakteristikama političkog bivstvovanja. Nije pogrešno ovdje upotrijebiti pojam "strukture" jer većina mislilaca o političkom razmišlja u nekom vidu binarnih opozicija. Carl Schmitt tako govori o opreci prijatelj-neprijatelj (Schmitt 2007), a Antonio Gramsci iz marksističke perspektive govori o elementu političkog opozicijom onih koji vladaju i onih kojima se vlada (Gramsci 1959; 1980). Za naše izlaganje posebno je važna misao Carla Schmitta, čijem "naslijeđu" na neki način pripada i Laclau. Ako slijedeći Marcharta ustvrdimo da možemo razlikovati asocijativni i disocijativni odnos spram poimanja političkog, prvi vezan uz Hannu Arendt, koja političko promatra kao prostor slobode i javne deliberacije, a drugi uz Carla 
Schmitta, koji političko tretira kao prostor borbe za moć i antagonizma (Marchart 2007: 38) - Ernesto Laclau veže se upravo uz potonju struju. Ovako Schmitt sažima svoje poimanje političkog:

Polje odnosa političkog stalno se mijenja, već prema silama i moćima koje se međusobno povezuju ili razdvajaju kako bi se održale [...]. Specifično političko razlikovanje, na koje se mogu svesti politička djelovanja i motivi, jest razlikovanje prijatelja i neprijatelja. Ono daje pojmovno određenje u smislu kriterija, ne kao iscrpna definicija ili prikaz sadržaja. [...] Smisao je razlikovanja prijatelja i neprijatelja da označi krajnji stupanj intenziteta povezivanja ili razdvajanja, asocijacije ili disocijacije; ono može teorijski ili praktički postojati, a da se ne moraju primijeniti sva ona moralna, estetska, ekonomska ili druga razlikovanja. Politički neprijatelj ne treba biti moralno zao, ne treba biti estetski ružan, ne mora nastupati kao privredni konkurent, pa čak može izgledati korisno s njim praviti poslove. On je naprosto onaj drugi, stranac, i za njegovu je bit dovoljno da je u osobito intenzivnom smislu egzistencijalno nešto drugo i strano, tako da su u ekstremnom slučaju mogući sukobi s njim, koji se ne mogu spriječiti ni nekim unaprijed utvrđenim općim normiranjem, ni presudom nekoga "nezainteresiranog" i stoga "nepristranog" trećeg. (Schmitt 2007: 61, 71)

Navođenje tako dugačkog pasusa ima svojih razloga - u Schmittovu promišljanju nalaze se brojne teme koje su utjecale na teorijsku poziciju Laclaua (i Mouffe): ${ }^{7}$ političko polje obilježeno nerazrješivim sukobom u kojem se prepoznaje konstitutivni moment toga istog polja, a čime se odbacuje mogućnost konsezualnog izmirenja i tjera na ne-reziginirano prihvaćanje vječite igre asocijacije i disocijacije političkih razlika (odnosno političko je strukturirano "igrom" logike ekvivalencije i logike diferencije, kako to "prevodi" Laclau).

Kako bismo pobliže ispitali Laclauov pojam političkog, moramo se osvrnuti na koncept diskursa te na razliku između društva i društvenog. Pod diskursom Laclau podrazumijeva beskonačnu igru razlika tijekom koje se operacijom fiksiranja/defiksiranja ekscesa značenja uspostavljaju čvorišne točke "smisla" i konstruira mogućnost pojave Društva (Marchart 2007:136). Relacijski karakter svakog identiteta u strukturi koja nema čvrsto, fiksirano središte, ${ }^{8}$ već je organizirana u otvorenom procesu "institucije/destitucije"

\footnotetext{
${ }^{7}$ Doduše, i Laclau i Mouffe su spremni samo do određene točke slijediti "kontroverznog" Schmitta (s čijom se "kontroverznošću" nećemo ovdje baviti). Mouffe to naglašava tako da moraju upotrijebiti "Schmitta protiv samog Schmitta", odnosno "koristeći kritiku liberalnog individualizma i racionalizma u redefiniranju liberalne demokracije, umjesto da je, poput Schmitta, odbacujemo" (Mouffe 2005: 14).

${ }^{8}$ Prema Derridi središte strukture ne može "upravljati strukturom" a istodobno "izmicati strukturalnosti" - "pojam centrirane strukture zapravo je pojam igre zasnovane, uspostavljene na temeljnoj nepomičnosti i na umirujućem uvjerenju, koje je sâmo izuzeto iz igre [...] u odsutnosti središta ili podrijetla sve postaje diskurs [...] sustav u kojem središnje, prvotno ili transcendentalno označeno nikada nije apsolutno prisutno izvan sustava razlika: odsutnost transcendentalnog označenog širi područje i igru značenja u beskonačnost" (Derrida 2007: 298-299).
} 
značenja, dovodi do toga da Laclau i Mouffe izriču jednu od svojih središnjih teza: društvo ne postoji. To jest, koncepcija društva kao ustanovljujućeg totaliteta svojih parcijalnih procesa mora biti odbačena u korist anti-esencijalističkog problematiziranja društvenog (Laclau i Mouffe 2001: 95-96). “'Društvo' nije ispravan objekt diskursa, ne postoji niti jedan osnovni princip koji fiksira - te stoga i konstituira - cijelo polje razlika. Nerješiva napetost unutrašnjost/izvanjsko uvjet je bilo kakve društvene prakse: nužnost postoji samo kao djelomično ograničavanje polja kontingencije" (Laclau i Mouffe 2001: 111). Ako, dakle, društvo ne postoji, čitavo je društveno (polje) upućeno na zaborav i prekrivanje te "praznine" oko koje je organiziran simbolički poredak. Ili, drukčije rečeno, "diskurs u kojem značenje ne može biti fiksirano nije ništa drugo nego diskurs psihotika" (Laclau 1990: 90) te je nužno obuzdavanje beskonačne igre razlika i uspostavljenje privremenog središta koje može jamčiti postojanje Društva. To "obuzdavanje" nastaje kao rezultat hegemonijske borbe i jezično-diskurzivnih praksi kojima se uspostavljaju čvorišne točke unutar označiteljske mreže ${ }^{9}$ i odigrava borba za hegemonizaciju praznih/lebdećih označitelja. ${ }^{10}$ "Društveno postoji samo kao uzaludan pokušaj da se ustanovi nemoguć objekt: društvo" (Laclau 1990: 92). Tako dolazimo do kategorije vrhovnog označitelja (ili rigidnog označitelja ili Gospodara-označitelja) koji "uključuje ideju partikularnog elementa koji prisvaja 'univerzalnu' strukturirajuću funkciju unutar određenog diskurzivnog polja" (Laclau i Mouffe 2005: 58), čime se uspostavlja privremena mreža značenja unutar određenog polja diskurzivnosti. Hegemonizacija lebdećih/ praznih označitelja za Laclaua je egzemplarni trenutak političkog.

Konceptom antagonizma Laclau i Mouffe odgovaraju na pitanje što je to što sprječava konačno zatvaranje društvenog i odgađa permanentnu stabilizaciju značenja. Konstitutivna rascijepljenost društvenog polja pojavljuje se kao točka neuspjeha u označiteljskom lancu, kao imanentan podbačaj pokušaja totalizacije, kao strukturalna trauma, točka inherentne nedovršenosti reprezentacije. Antagonizam predstavlja ne objektivne društvene odnose, već limit svake objektivnosti. Nijedan antagonistički blok ne uspijeva upotpuniti vlastiti identitet jer ga sprječava diskurzivna izvanjskost Drugoga (Laclau 2006: 104-105; Laclau i Mouffe 2001: 122). ${ }^{11}$

${ }^{9}$ Čvorišne točke ekvivalentne su onomu što Lacan naziva point de caption ili prošivni bod. Riječ je o točkama koje poput čvora vezuje označitelja i označeno. Takvo prošivanje zaustavlja neograničenu cirkulaciju značenja i daje iluziju stabilne strukture značenja (Evans 1996: 151).

${ }^{10} \mathrm{U}$ trenutku kada neki partikularni sadržaj preuzima na sebe ulogu označitelja odsutne punine društvenog, on postaje prazni označitelj (koji doduše nikada nije potpuno prazan, već uvijek samo tendencionalno). "Prazni označitelj se može pojaviti samo ukoliko postoji strukturna nemogućnost u procesu označavanja kao takvom” (Laclau 2007: 37).

${ }^{11}$ Konstitutivna izvanjskost (Derrida) jest trenutak sučeljavanja diskursa s prisutnošću Drugoga koja ne može biti asimilirana na unutardiskurzivnu diferencijalnost. Ta "forma radikalne drugotnosti" u isto je vrijeme preduvjet i prepreka konstituiranju diskursa (Torfing 1999: 299). Ili, kao što tvrdi Hall, "suprotno 
Ako je jezik sustav razlika, antagonizam je neuspjeh te razlike: ali u tom smislu da pozicionirajući se unutar limita jezika može postojati jedino kao njegovo remećenje [...] svaki jezik i svako društvo konstituirano je kao potiskivanje svijesti o nemogućnosti koja ih presijeca. (Laclau i Mouffe 200: 125)

Koncept antagonizma u političko-društvenom polju ekvivalentan je Lacanovu konceptu Realnog, ${ }^{12}$ a Žižek ga definira na sljedeći način:

[A]ntagonizam je upravo takvo nemoguće jezgro, određena granica koja po sebi nije ništa; ona mora biti retroaktivno konstruirana iz niza njezinih efekata kao traumatična točka koja im izmiče; ona sprečava zatvaranje društvenog polja. (Žižek 2002: 221)

Iz Žižekove perspektive u kojoj je antagonizam zapravo uvijek klasni antagonizam (što je za Laclaua redukcionistička gesta koju odbija) nemogućnost reprezentacije je posljedica toga što "nema neutralnog Svega određenog društva - svako 'Sve' potajno dovodi određenu klasu u povlašteni položaj” (Žižek 2013: 41). Laclauova misao je da antagonizam nikad nije samo klasni antagonizam, odnosno klasna razlika je tek jedna u nizu razlika koje presijecaju polje društvenog. Proliferacija identifikacijskih tvorbi u suvremenom društvu onemogućava simplifikaciju stratifikacijske strukture, što se prema Laclauu na teorijskoj razini održava u postmarksističkom paradigmatskom pomaku od klasne centriranosti prema decentriranim, nadodređenim subjektnim pozicijama koje omogućuju pojavljivanje radikalno-demokratskog prostora.

Ako je društvo, dakle, diskurzivni konstrukt koji nastaje i održava se u hegemonijskom polju i rezultat je političke "reaktivacije" društvenog, treba istaknuti kako političko opstoji tek u artikulacijskoj praksi kao posljedica dislokacije strukture i neravnomjerne distribucije moći. Kada bi moć bila apsolutna, politički moment bio bi nemoguć. ${ }^{33}$ "I Hobbesov monarh i Platonov filozof-kralj koncentriraju svu moć u svojim rukama, i trenutak rasprave,

obliku u kojem ih najčešće prizivaju, identiteti se konstruiraju kroz razlike, a ne izvan njih. Ovo za sobom povlači radikalno uznemirujuću spoznaju da se pozitivno značenje bilo kojeg termina, pa time i njegov identitet, konstruira samo preko odnosa s Drugim, u odnosu prema onomu što ono nije, prema onomu što mu nedostaje" (Hall 2001: 219).

${ }^{12} \mathrm{U}$ Lacanovoj trijadi simboličko-imaginarno-realno, realno (koje ne treba zamijeniti za realnost) jest dimenzija koja izmiče simbolički posredovanoj "realnosti": ono je smješteno onkraj simboličkog i izvan jezika, opire se simbolizaciji i uvijek se vraća na svoje mjesto. "Realno nije transcendentni pozitivni entitet, koji postoji negdje $s$ onu stranu simboličkog poretka poput neke njemu nedostupne tvrde jezgre, neke vrste kantovske 'Stvari-po-sebi' - Realno u sebi nije apsolutno ništa, samo praznina, šupljina u simboličkoj strukturi koja markira neku središnju nemogućnost" (Žižek 2002: 233). Istodobno, ta "središnja nemogućnost" jest "manjak oko kojega je strukturiran simbolički poredak" (isto: 229).

13 "Ako A ima apsolutnu moć u društvu, tada njezini efekti na B, C i D potpuno konstruiraju njihov identitet [...] to bi značilo da ostale skupine u društvu nemaju drugi identitet osim onog koji proizlazi iz te moći te bi i one kao rezultat bile dio identiteta dominantne skupine" (Laclau i Zac 1994: 18). 
razmirica i antagonizma koji karakterizira politiku je eliminiran" (Laclau 1990: 71). Husserlovim terminima, ako je "društveno teren sedimentiranih diskurzivnih praksi [...] političko se definira kao trenutak institucionalizacije društvenog jednako kao i trenutak reaktivacije kontingente prirode svake institucije" (Marchart 2007: 138). Ipak, političko se kao takvo ne iscrpljuje isključivo u gestama reaktivacije i institucionalizacije, ono je uvijek inherentno privučeno sedimentaciji vlastite "kontingente prirode" i uspostavljanju "nove objektivnosti", što na koncu dovodi do povlačenja političkog. Dakle, pojavljivanje političkog u sebi imanentno sadrži sjeme vlastite negacije, to jest hegemonijski uspjeh artikulacijske prakse određene političke opcije teži potiskivanju kontingentnih korijena i pomak prema naturalizirajućem diskurzivnom odnošenju spram svojih uspjeha (Marchart 2007: 139).

\section{MIT I "STRUKTURA"}

Ono što će nas zanimati u nastavku jest upravo "uloga" mita i mitskog u tom procesu nemogućnosti reprezentacije društva i konstruiranja prostora političkog. Za Laclaua mit nije primitivna svijest ili nešto iracionalno već "princip reprezentacije neke situacije, čiji su pojmovi izvanjski onome što je reprezentatibilno u objektivnoj prostornosti koju je konstituirala dana struktura. 'Objektivni' uvjet pojavljivanja mita je, dakle, dislokacija strukture" (Laclau 1990: 61). Mit stvara "novi prostor reprezentacije" i time se pojavljuje kao kritička točka naspram diskursa dominantnog poretka. "Ali nije riječ o 'strukturalnosti' dominantne strukture kojoj je mitski prostor suprotstavljen, već njezinim de-strukturirajućim efektima" (Laclau 1990: 62). Time, baš kao i kod Sorela, mit ima svojevrsnu kritičku i opozicijsku funkciju, on ubrzava destrukturiranje dominantnog poretka i stvara mogućnost upisivanja različitih suprotstavljenih narativa. Razlika je ipak, kao što smo istaknuli, u tome što se Sorel u svojem teoretiziranju vodi reprezentacijskom logikom u kojoj je mit oruđe ujedinjenja alijenirane radničke klase i diskurzivna os okupljanja već konstruiranih identiteta koji tek moraju biti probuđeni iz svojeg historijskog drijemeža, dok kod Laclaua nalazimo de-supstancijalizirane identitete koji ne postoje izvan procesa identifikacijskih tvorbi.

Karakter mita je dvojak, on stoji kao sadržaj vlastitog iskaza, ali i kao metaforička reprezentacija odsutne punine. U trenutku kad mit transcendira vlastiti partikularitet on postaje ono što Laclau naziva socijalni imaginarij (poput prosvjetiteljstva, komunističkih eshatologija ili pozitivističke koncepcije napretka). Mitski prostor tada više nije organiziran isključivo oko vlastitog narativa, već postaje "platforma" za širenje lanca ekvivalencije i stvaranje antagonističkog bloka. "Pojam mita i socijalnog imaginarija čine ideološke forme diskursa čiji je cilj konstruirati društvo i društvene agente 
kao pozitivne i kompletno prošivene identitete" (Torfing 1999: 115). Treba primijetiti kako se socijalni imaginarij nalazi jednako u mitskom kao i u strukturnom pokušaju da se pronađe prikladan narativ koji će adresirati pitanje Društva.

S druge strane, i mitsko i političko izviru iz dislokacije strukture. Ako je mit svojevrstan modus reprezentacije (koji je najvidljiviji u rascjepima velikih društveno-političkih kriza), onda se političko pojavljuje u rascjepu između dominantne strukture značenja nekog historijskog trenutka i posljedica de-strukturiranja koje svoj izraz nalaze u mitskom diskursu. Kad bi struktura bila bez ostatka prošivena i moć koncentrirana u jednom centru, pojavljivanje mitskih narativa nužno bi slijedilo logiku dominantnih praksi. Dakako, valja nam se zapitati, ako mitsko ne izvire iz "strukturne objektivnosti", otkuda se pojavljuje? Za Laclaua nejednaka distribucija moći (poglavito u suvremenim demokratskim društvima u kojima mjesto moći ostaje "prazno", bez transcendentalnog jamstva koje osigurava intenzitet centralizacije) - dovodi do toga da se unutar društvenog prostora pojavljuje mogućnost upisivanja zahtjeva i nezadovoljstva koji s vremenom stvaraju diskurzivnu "kritičnu masu" okupljenu u lancu ekvivalencija. U trenutku kada mit prelazi u socijalni imaginarij, i kada njegov doslovni sadržaj prepušta mjesto formi reprezentacije same odsutne punine društva, partikularni mitski sadržaji blijede i stvara se horizont u kojem je moguće upisati "bilo koji" sadržaj (Laclau 1990: 62-64). Tendencionalni prazni označitelji sve se više udaljuju od svojih partikularnih "temelja" i preuzimaju funkciju univerzalnih centara. Dakako, ta univerzalnost je za Laclaua uvijek "kontaminirana univerzalnost", univerzalnost stvorena nestalnom hegemonijskom pretenzijom na prazno mjesto moći, a ne nekom "ontološkom" privilegiranošću određene grupacije. Ili, drukčije rečeno:

[I]spražnjenost koja se može ispuniti samo pojedinačnim, ali koje, putem same svoje praznine, proizvodi niz ključnih učinaka u strukturiranju i destrukturiranju društvenih odnosa [...]. Ukoliko ta složena dijalektika između ontičkog sadržaja i ontološke dimenzije, strukturira samu društvenu stvarnost, ona također strukturira identitet društvenih posrednika. (Laclau u Butler i dr. 2007: 62)

Tenzija partikularno-univerzalno jest "kreacijski" element političko-društvenog polja. Pritom za Laclaua nema korelacije između same dislokacije strukture i mitskih narativa koji proizlaze iz nje: sam "sadržaj" tih narativa ne može biti deduciran iz strukturnih manjkavosti (1990: 65). Mit je tek "odgovor" na nepostavljeno pitanje, odgovor koji nije nužno u korelativnoj vezi sa svojim izvorištem, to jest ta "veza" je uvijek kontingente naravi i konstruira se u samom činu "iskazivanja", a ne u reprezentaciji "datosti". Za vrijeme 
političko-društvene krize, kada strukturne dislokacije postaju transparentne kritičnoj masi socijalnih aktera, ne postoji onaj jedan narativ koji neutralno i objektivno odgovara na izazove i ključ je za njihovo prevladavanje; postoje tek brojni narativi koji uspostavljaju razne prostore reprezentacije i (re)artikuliraju same strukturne (re)artikulacije. Niti dominantni diskurs strukture niti mitski diskursi dislokacije nemaju objektivan uvid u historijski trenutak koji bi nekoj socijalnoj grupaciji jamčio da se može pozvati na društvenu istinu. Društvo kao tendencija ka totalitetu i harmoniji (taj tisućljetni san o Idealnom gradu!) "postoji" istodobno kao nužnost dominantnog diskursa da ustoliči sam sebe, ali i kao mitski odgovor na nemogućnost konačnog prošivanja. I socijalistički, i neoliberalni, i nacionalistički narativi tek su pokušaji da se "obuzda" ta neizdrživo neiscrpljiva igra razlika i da se konstruira središte koje će poput epicentra emitirati "diktirani" smisao uz pomoć označiteljske mreže. Ako "izgovoriti kontingenta artikulacija znači izraziti središnju dimenziju 'politike'" (Laclau i Mouffe 2005: 58), tada govoriti o mitskom znači uputiti na diskurzivne čestice koje nastanjuju teren političkog i koje u svakom trenutku mogu biti "reaktivirane" u hegemonijskom previranju.

\section{ZAKLJUČAK}

Osvrnimo se na kraju na Laclauovu tvrdnju da "svaka epoha usvaja sliku o sebi samoj - određeni horizont, koliko god maglovit i neprecizan, koji na neki način ujedinjuje cijelo njezino iskustvo" (Laclau 1990: 3). Iz onoga što smo pokazali ta slika epohe o sebi samoj uvijek je rascijepljena između dominantnog diskursa koji pokušava utjeloviti "objektivnost" nekog historijskog trenutka i mitskih narativa kao odgovora na konstitutivnu strukturnu nemogućnost i nedovršenost. Upravo taj rascjep priječi "epohu" da se iscrpi u gesti samoreprezentacije i da se uobliči njezina konačna istina. Mitski "sadržaji" kojima je ispunjen prostor između Društva i društvenog, a koji je ujedno i prostor pojavljivanja političkog, za Laclaua su nezaobilazan sastojak hegemonijske borbe. Baš poput Gramscijeva inzistiranja na osjećaju za nacionalno-popularno, tako je i Laclau svjestan "snage" mitskog koja se ne može ignorirati u političkoj areni. Dapače, za njega je današnje vrijeme, koje naziva epohom dezorganiziranog kapitalizma, obilježeno proliferacijom mitskih narativa koji sve više postaju uvjet i katalizator socijalne reprodukcije na račun strukturne objektivnosti (Laclau 1990: 68). Time mit postaje ne samo priča kojom se politički prostor puni emotivnim i iracionalnim nabojem već jedan od preduvjeta pojavljivanja političkog; mitsko koje adresira manjkavosti strukturne objektivnosti daje (narativnu) formu rascjepu društvenog kao momentu političkog. Iz šire perspektive teorije diskursa odnos između 
političkog i mitskog, kako ga vidi Laclau, ima nekoliko metodoloških posljedica koje ćemo na samom kraju pokušati sažeti na sljedeći način:

A. Prepoznavanje mitskih "sadržaja" čiji je izvor dislokacija strukture i koji se zato pojavljuju kao ne-objektivni spram dane strukturne objektivnosti (ili "iracionalni" spram dane strukturne "racionalnosti") omogućuje da se izolira artikulacijski princip određenog političkog diskursa, odnosno utvrdi "kritična točka" kondenzacije partikulariteta u lanac ekvivalencija i formiranje socijalnog imaginarija.

B. "Struktura" nije ništa doli socijalni imaginarij koji potiskuje svoje kontingente temelje i naturalizira svoje hegemonijsko podrijetlo, stoga interpretacija političkih diskursa mora biti osjetljiva na dijalektičku vezu između mitskosti strukture i strukturalnosti mitskoga.

C. Pokušaj "izolacije” određenog mitskog sadržaja koji zauzima povlašteno mjesto unutar lanca ekvivalencije mora se poduzeti s obzirom na transcendirajući partikularitet čija transcendirajuća gesta re-artikulira vlastiti mitski sadržaj, ali i čitav lanac partikulariteta "pod sobom".

\section{NAVEDENA LITERATURA I IZVORI}

Butler, Judith, Ernesto Laclau i Slavoj Žižek. 2007. Kontingencija, hegemonija, univerzalnost. Suvremene rasprave na ljevici. Zagreb: Naklada Jesenski i Turk.

Cassirer, Ernst. 1972. Mit o državi. Beograd: Nolit.

Cassirer, Ernst. 1978. Ogled o čovjeku. Zagreb: Naprijed.

Derrida, Jacques. 2007. Pisanje i razlika. Sarajevo: Šahinpašić.

Evans, Dylan. 1996. An Introductory Dictionary of Lacanian Psychoanalysis. London, New York: Routledge.

Gramsci, Antonio. 1959. Izabrana dela. Beograd: Kultura.

Gramsci, Antonio. 1980. Filozofija istorije i politike. Izbor iz dela; pisma iz zatvora. Beograd: Slovo ljubve.

Hall, Stuart. "Kome treba 'identitet'?" Reč 64/10: 215-233.

Laclau, Ernesto. 1990. New Reflections on the Revolution of Our Time. London: Verso.

Laclau, Ernesto i Lilian Zac. 1994. "Minding the Gap. Subject of Politics". U The Making of Political Identites. Ernesto Laclau, ur. London, New York: Verso.

Laclau, Ernesto. 1996. "The Death and Resurrection of the Theory of Ideology". Journal of Political Ideologies 1/3: 201-220. [http://dx.doi.org/10.1080/13569319608420738]

Laclau, Ernesto. 2005. On Populist Reason. London: Verso.

Laclau, Ernesto. 2006. “Ideology and post-Marxism”. Journal of Political Ideologies 11/2: 103114. [http://dx.doi.org/10.1080/13569310600687882]

Laclau, Ernesto. 2007. Emancipation(s). London: Verso.

Laclau, Ernesto i Chantal Mouffe. 2001. Hegemony and Socialist Strategy. Towards a Radical Democratic Politics. London: Verso. 
Laclau, Ernesto i Chantal Mouffe. 2005. "Predgovor drugom izdanju knjige Hegemonija i socijalistička strategija". Diskrepancija 6/10.

Laclau, Ernesto i Chantal Mouffe. 2007. Postmarksizam bez pardona. Zluradi paradi.

Lalović, Dragutin. 2012. “'Politička razlika' kao temeljni spoznajni izazov političke teorije (o pojmovnom razlikovanju politike i političkoga)". Politička misao 49/1: 171-183.

Lévi-Strauss, Claude. 1989. Strukturalna antropologija. Zagreb: Stvarnost.

Marchart, Oliver. 2007. Post-Foundational Political Thought. Political Difference in Nancy, Lefort, Badiou and Laclau. Edinburgh: Edinburgh University Press. [http://dx.doi. org/10.3366/edinburgh/9780748624973.001.0001]

Maslov, Gordan. 2009. "Laclau i Mouffe o (ne)mogućnosti društva”. Filozofska Istraživanja 29/1: 179-190.

Mouffe, Chantal. 2005. On the Political. London, New York: Routledge.

Schmitt, Carl. 2007. Politički spisi. Zagreb: Politička kultura.

Solar, Milivoj. 2000. Granice znanosti o književnosti. Zagreb: Naklada Pavičić.

Sorel, Georges. 1980. Revolucija i nasilje. Zagreb: Globus.

Torfing, Jacob. 1999. New Theories of Discourse. Oxford: Blackwell Publishers Ltd.

Žižek, Slavoj. 2002. Sublimni objekt ideologije. Zagreb: Arkzin.

Žižek, Slavoj. 2006. Škakljivi subjekt. Sarajevo: Šahinpašić.

Žižek, Slavoj. 2013. Godina opasnog sanjanja. Zaprešić: Fraktura

\title{
ON THE RELATIONSHIP BETWEEN THE MYTHIC AND THE POLITICAL IN THE WORKS OF ERNESTO LACLAU
}

\author{
SUMMARY
}

\begin{abstract}
This paper deals with the conceptual relationship between the mythical and the political in the work of the political theorist Ernesto Laclau. The post-structuralist and post-Marxist perspective from which Laclau speaks is imbued with a strong anti-essentialist ethos and focuses on the deconstruction of naturalization and totalization in the signifying practice within the political field. For Laclau, the myth creates "a new space of representation" and thus appears as a critical point of order against the dominant discourse. In order to adequately respond to the problem analysed in this paper, we examine Laclau's distinction between the society and the social, as well as the concept of the social imaginary. We also briefly look back at some of the authors who influenced the theoretical position of Ernesto Laclau: Sorel, Schmitt, Derrida ...
\end{abstract}

Key words: myth, political, discourse, post-structuralism, antagonism 